\title{
Karakterisasi Tomat M1 Hasil Iradiasi Sinar Gamma 495 Gy
}

\section{Characterization M1 Tomato Resulted by Induced Gamma Ray Irradiation 495 Gy}

\author{
Uswatun Hasanah $^{1}$, Surjono Hadi Sutjahjo ${ }^{1}$, Siti Marwiyah ${ }^{1}$ \\ ${ }^{1}$ Departemen Agronomi dan Hortikultura, Fakultas Pertanian, Institut Pertanian Bogor \\ (Bogor Agricultural University), Jalan Meranti, Kampus IPB Darmaga, Bogor 16680, Indonesia \\ Telp. \& Faks. 62-251-8629353 e-mail agronipb@indo.net.id \\ *Penulis korespondensi: surjonohadisutjahjo@yahoo.co.id \\ Disetujui 7 Januari 2015/ Publish online 15 januari 2015
}

\begin{abstract}
This research aimed to obtain information about the performance of $M 1$ tomato plants resulted from gamma irradiation treatment dose 495 Gy. Materials used are 40 genotypes of tomato with the treatment of 495 Gy of gamma ray irradiation. This research was conducted at the Leuwikopo Research Field and Post Harvest Laboratory of Agronomy and Horticulture Department, Bogor Agricultural University from November 2014 until March 2015. The characterization was conducted by comparing the qualitative and quantitative characters between M1 and MO genotypes. The result of this research elucidated the gamma rays treatment cause the diversity of genetic performance, both in qualitative or quantitative characters.There are several genotypes M1 which have different qualitative performance to the control, namely Kefaminano 6, Kefaminano 4, Situbondo GL, Lombok 4, Lombok 1, Gondol 2, Kudamati 1, Aceh 1, Makassar 3, Bogor Cibanteng, Berlian, CLN 4046, and Kemir. Based on the weight of the yield, there are three genotypes with superior production compared to control plants, namely Aceh 5, Lombok 4, and Kefaminano 4.
\end{abstract}

Keyword : characterization, gamma ray, genotype, mutation, tomato

ABSTRAK

Penelitian ini bertujuan untuk memperoleh informasi keragaan tanaman tomat M1 hasil iradiasi sinar gamma dosis 495 Gy. Bahan yang digunakan merupakan 40 genotipe benih tomat hasil eksplorasi yang diberi perlakuan iradiasi sinar gamma 495 Gy. Penelitian ini dilaksanakan di Kebun Percobaan Leuwikopo dan Laboratorium Pascapanen Departemen Agronomi dan Hortikultura, Institut Pertanian Bogor pada bulan November 2014 hingga Maret 2015. Karakterisasi dilakukan dengan membandingkan karakter kualitatif dan kuantatif antara genotipe M1 dan MO. Hasil penelitian menunjukkan perlakuan sinar gamma menyebabkan adanya keragaman pada keragaan genotipe, baik pada karakter kualitatif maupun kuantitatif. Terdapat beberapa genotipe M1 yang memiliki keragaan kualitatif berbeda dibandingkan kontrolnya yaitu Kefaminano 6, Kefaminano 4, Situbondo GL, Lombok 4, Lombok 1, Gondol 2, Kudamati 1, Aceh 1, Makassar 3, Bogor Cibanteng, Berlian, CLN 4046, dan Kemir. Berdasarkan bobot panen didapatkan tiga genotipe dengan produksi lebih unggul dibandingkan dengan tanaman kontrol yaitu Aceh 5 , Lombok 4, dan Kefaminano 4.

Kata kunci : genotipe, karakterisasi, mutasi, sinar gamma, tomat 


\section{PENDAHULUAN}

Tomat (Lycopersicon esculentum Mill.) merupakan salah satu tanaman hortikultura yang menjadi kebutuhan masyarakat umum (Wahyudi, 2012). Jumlah konsumsi tomat pada tahun 2007 mencapai $2.09 \mathrm{~kg}$ tahun $^{-1}$ per kapita dan meningkat $2.32 \mathrm{~kg}$ tahun $^{-1}$ per kapita pada tahun 2008 (PUSDATIN 2008). Tomat mengandung beberapa nutrisi penting yaitu, vitamin $\mathrm{C}$, sumber antioksidan, likopen, dan nitrosamine (Lingga, 2010). Produksi tomat nasional tahun 2013 mencapai 992780 ton, produksi meningkat dari tahun 2012 dengan angka produksi 893504 (BPSRI, 2013a). Luas lahan produksi tomat pada tahun 2012 seluas 56724 ha, pada tahun 2013 luas lahan meningkat seluas 59758 ha (BPSRI, 2013b). Hingga saat ini Indonesia masih melakukan impor baik dalam bentuk olahan, maupun tomat segar dengan nilai 307893 US\$, dan nilai ekpor 128091 US\$ (PUSDATIN, 2014). Jumlah produksi tomat dan kegiatan impor yang berfluktuasi setiap tahun berdampak terhadap harga tomat yang tidak pernah stabil setiap tahunnya. Salah satu cara agar tanaman tomat memiliki produksi yang tinggi dan terdapat di pasar sepanjang tahun dan musim, diperlukan varietas dengan produksi buah tinggi, tahan layu bakteri, dan toleran pecah buah.

Pemuliaan tanaman dapat memberikan solusi alternatif dalam permasalahan masyarakat budidaya tanaman tomat. Salah satunya dengan merakit varietas unggul baru yang mempunyai kemampuan lebih tinggi dalam menghasilkan biomassa ke bagian yang dapat dipanen. Perbaikan resistensi terhadap hama dan penyakit, atau memperbaiki tingkat resistensi dapat dilakukan dengan menyusun ideotipe varietas (Syukur et al., 2012).

Koleksi plasma nutfah merupakan sumber kekayaan keragaman genetik bagi kegiatan pemuliaan tanaman. Koleksi plasma nutfah merupakan hasil eksplorasi dari tempat dimana terdapat keragaman genetik yang tinggi, yaitu dari tempat asal berkembangnya spesies tanaman itu atau dari tempat dimana tanaman itu secara intensif telah dibudidayakan sejak lama (Syukur et al., 2012). Keragaman genetik yang tinggi dari ekplorasi dapat dijadikan sebagai galur-galur harapan hasil pemuliaan tanaman, salah satu teknik untuk mendapatkan keragaman genetik ialah dengan teknik mutasi iradiasi sinar gamma.

Mutasi dapat terjadi secara alami atau spontan, dan mutasi terinduksi (Allard, 1995). Mutasi adalah suatu perubahan yang terjadi pada materi genetik suatu organisme yang menyebabkan perubahan ekspresinya. Organisme baru hasil mutasi disebut mutan sedangkan genotipe sebelum terjadi proses mutasi diberi istilah tipe liar (Yudiwanti, 2006). Menurut Aisyah (2006) mutasi dapat terjadi pada seluruh bagian tubuh tanaman dan setiap fase pertumbuhan tanaman, namun lebih banyak terjadi pada bagian yang sedang aktif mengadakan pembelahan sel seperti tunas, biji, dan sebagainya.

Penelitian ini bertujuan untuk memperoleh informasi keragaan tanaman tomat M1 hasil iradiasi sinar gamma dosis 495 Gray. Hasil penelitian diharapkan terdapat keragaan tanaman tomat M1 yang berbeda dibandingkan kontrolnya dengan karakter yang lebih baik, serta menunjukkan keragaan produksi unggul.

\section{BAHAN DAN METODE}

Percobaan ini dilaksanakan di Kebun Percobaan Leuwikopo Departemen Agronomi dan Hortikultura, IPB, Dramaga, Bogor pada bulan November 2014 hingga Maret 2015. Pengamatan laboratorium akan dilaksanakan di Laboratorium Pasca Panen Departemen Agronomi dan Hortikultura, Fakultas Pertanian, IPB. Perlakuan iradiasi sinar gamma tanaman tomat dilaksanakan di Pusat Aplikasi Teknologi Isotop dan Radiasi (PAIR), Badan Tenaga Nuklir Nasional (BATAN), Pasar Jumat, Jakarta Selatan. Bahan tanam yang digunakan dalam percobaan ini adalah 40 genotipe tomat yang diberi perlakuan iradiasi sinar gamma. Sejumlah 50 benih setiap genotipe pada dosis 495 Gy dan kontrol (tanpa perlakuan irradiasi). Bahan lain yang digunakan ialah pupuk dasar Urea $300 \mathrm{~kg} \mathrm{ha}^{-1}, \mathrm{SP}-36500 \mathrm{~kg}$ $\mathrm{ha}^{-1}, \mathrm{KCl} 300 \mathrm{~kg} \mathrm{ha}^{-1}$, NPK mutiara untuk pupuk kocor $250 \mathrm{~mL} /$ tanaman $(10 \mathrm{~g}$ NPK mutiara dalam $1 \mathrm{~L}$ air), selain itu digunakan juga insektisida karbofuran. Alat yang digunakan adalah alat-alat pertanian, ajir, plastik, timbangan digital, mulsa hitam perak, meteran, penetrometer, hand refraktometer, jangka sorong, alat tulis, penggaris, dan label.

Percobaan dimulai dengan penyemaian benih yang dilaksanakan dalam tray berisi media semai campuran tanah dan pupuk kandang (2:1 $\mathrm{v} / \mathrm{v})$. Pemeliharaan rutin meliputi pemupukan daun dan penyiraman. Persiapan selanjutnya adalah pengolahan lahan meliputi pembersihan gulma, pemberian pupuk kandang sebanyak 1500 $\mathrm{kg} / \mathrm{ha}$, pemasangan mulsa hitam perak, dan membuat bedengan ukuran $1 \mathrm{~m}$ x $15 \mathrm{~m}$ sebanyak empat puluh bedengan dengan jarak lubang tanam $60 \mathrm{~cm}$ x $60 \mathrm{~cm}$, ditambah 20 bedeng untuk tetua.

Bibit dipindah tanam ketika telah berumur tiga minggu setelah semai. Penanaman diawali 
dengan menyiram bibit tomat hingga terlihat lembap, lubang tanam dibuat sedalam 8-10 cm dengan tugal. Pemasangan ajir dilakukan saat tanam dengan sistem tegak. Pemeliharaan meliputi penyulaman, pewiwilan tunas air, pemupukan, dan pengendalian hama penyakit. Pemupukan rutin dengan pupuk kocor. Pengendalian hama dan penyakit dilakukan secara kimiawi sesuai dengan tingkat serangan, jenis hama dan penyakit yang menyerang tanaman tomat. Pemanenan dilakukan setiap minggu selama enam kali panen, terhadap buah yang $75 \%$ telah berwarna merah hingga merah total.

Pengamatan dilakukan, yaitu karakter kuantitatif dan karakter kualitatif yang mengacu pada Internasional Union for the Protection of New Varieties of Plant (UPOV 2010-2011) dan Florida Tomato Committee (2015). Pengamatan dilakukan terhadap semua tanaman tomat dengan perlakuan iradiasi sinar gamma $495 \mathrm{~Gy}$, dan lima tanaman contoh pada kontrol. Karakter kuantitatif meliputi daya tumbuh (\%), umur berbunga dan umur panen (HST), tinggi tanaman $(\mathrm{cm})$, jumlah cabang utama, diameter batang $(\mathrm{cm})$, diameter buah $(\mathrm{mm})$, panjang buah $(\mathrm{mm})$, panjang pedisel $(\mathrm{mm})$, bobot panen $(\mathrm{g})$, bobot per buah $(\mathrm{g})$, padatan terlarut total $\left({ }^{\circ} \mathrm{Brix}\right)$, dan kekerasan buah $\left(\mathrm{mm} 50^{-1} \mathrm{~g} \mathrm{5}^{-1} \mathrm{~s}\right)$. Karakter kualitatif meliputi arah perbentukan daun, tipe helai daun, tipe kerutan daun, letak petiole, tipe susunan bunga, tipe pemotongan tangkai, bentuk buah secara membujur, ribbing, bentuk ujung buah, jumlah lokus, diameter lokus, warna buah, dan cracking atau pecah buah (Susila, 1995). Analisis data dilakukan dengan menggunakan program MINITAB, dan MS Excel 2007, meliputi pendugaan nilai tengah, standart deviasi, dan koefisien keragaman.

\section{HASIL DAN PEMBAHASAN}

\section{Kondisi umum}

Tanaman tomat saat di persemaian membutuhkan air yang banyak, kemudian menurun selama vegetatif dan di lapangan meningkat kembali saat tanaman akan berbunga, serta mencapai maksimum saat buah tomat mulai matang (Hidayat, 1997).

Menurut Rubatzky dan Yamaguchi (1999), suhu optimum tomat $18^{\circ} \mathrm{C}$ dan $24^{\circ} \mathrm{C}$, sedangkan suhu di lapangan selama penelitian 25.6-26. $3^{\circ} \mathrm{C}$. Suhu tersebut masih berada pada rentang yang sesuai untuk pertumbuhan dan perkembangan tanaman tomat, nilai kelembapan udara di lapang 64-85\%.

Kondisi pertumbuhan dan perkembangan secara umum memiliki gejala yang sama, pada umur 4 MST beberapa genotipe mengalami penghambatan pertumbuhan, sehingga menyebabkan tanaman mati. Jumlah genotipe tomat mutasi yang dapat tumbuh dengan baik adalah 20 genotipe dari 40 genotipe yang ditanam.

Pecah buah dan penyakit layu bakteri diketahui menyerang beberapa tanaman tomat diawali dengan adanya gejala pada pangkal buah yang menjadi kuning kecoklatan, lalu membusuk dan rontok. Gejala ini banyak terjadi pada musim hujan saat temperatur dan kelembapan tinggi. Layu bakteri disebabkan oleh bakteri Ralstonia solanacearum, banyak menyerang tanaman tomat di dataran rendah. Gejala serangan yang ditandai dengan melayunya beberapa daun muda pada pucuk tanaman dan menguningnya daun-daun tua. Pengendalian secara kultur teknis dapat dilakukan dengan pergiliran tanaman yang bukan merupakan inangnya, dan secara kimiawi dengan menggunakan Streptomisin sulfat 15\%, Oksitetra siklin $1.5 \%$, dan Streptomisin sulfat $25 \%$ (Cahyono, 2008).

\section{Sifat Kualitatif}

Sifat kualitatif pada karakter pertumbuhan. Seluruh genotipe tomat M1 memiliki karakter arah perbentukan daun yang sama dengan tetuanya (M0) yaitu semi-erect, dimana arah daun menuju keatas. Tanaman M1 dan M0 memiliki karakter kerutan daun yang sama yaitu creasing.

Pembagian helai daun pada sebelas genotipe M1 memiliki bentuk bipinnate, sedangkan sembilan genotipe lainnya memiliki bentuk helai daun pinnate (Tabel 1). Karakter pembagian helai daun pada tanaman M1 umumnya sama dengan tipe pada M0 kecuali genotipe Kefaminano 6 dan Kefaminano 4 memiliki bentuk bipinnate, pada genotipe Lombok 4 dengan bentuk pinnate. Genotipe Kefaminano 6 dan Kefaminano 4 M1 memiliki bentuk pinnate, sedangkan genotipe Lombok 4 memiliki tipe helai daun bipinnate. Hasil ini sejalan dengan penelitian Ratnasari (2007) bahwa penginduksian sinar gamma menghasilkan keragaman bentuk daun pada tanaman melati (Jasmimum spp). Hasil yang sama pada penelitian Purwati (2009) munculnya keragaman bentuk daun tanaman Artemisia (Artemisia aпnиа L) hasil penginduksian sinar gamma. 
Tabel 1. Keragaan kualitatif karakter arah pembentukan daun, tipe helai daun, dan tipe kerutan daun 20 genotipe tomat M1 dan M0

\begin{tabular}{|c|c|c|c|c|c|c|}
\hline \multirow{2}{*}{ Genotipe } & \multicolumn{2}{|c|}{ Arah perbentukan daun } & \multicolumn{2}{|c|}{ Tipe helai daun } & \multicolumn{2}{|c|}{ Tipe kerutan daun } \\
\hline & M1 & M0 & M1 & M0 & M1 & M0 \\
\hline Kudamati 1 & Semi-erect & Semi-erect & Bipinnate & Bipinnate & Creasing & Creasing \\
\hline Kefaminano 6 & Semi-erect & Semi-erect & Pinnate & Bipinnate & Creasing & Creasing \\
\hline Aceh 1 & Semi-erect & Semi-erect & Bipinnate & Bipinnate & Creasing & Creasing \\
\hline Lombok1 & Semi-erect & Semi-erect & Pinnate & Pinnate & Creasing & Creasing \\
\hline Aceh 5 & Semi-erect & Semi-erect & Bipinnate & Bipinnate & Creasing & Creasing \\
\hline Kemir & Semi-erect & Semi-erect & Pinnate & Pinnate & Creasing & Creasing \\
\hline Chung & Semi-erect & Semi-erect & Bipinnate & Bipinnate & Creasing & Creasing \\
\hline Jember & Semi-erect & Semi-erect & Bipinnate & Bipinnate & Creasing & Creasing \\
\hline Situbondo GL & Semi-erect & Semi-erect & Bipinnate & Bipinnate & Creasing & Creasing \\
\hline Makassar3 & Semi-erect & Semi-erect & Bipinnate & Bipinnate & Creasing & Creasing \\
\hline Situbondo BK & Semi-erect & Semi-erect & Pinnate & Pinnate & Creasing & Creasing \\
\hline Lombok 3 & Semi-erect & Semi-erect & Bipinnate & Bipinnate & Creasing & Creasing \\
\hline Lombok 4 & Semi-erect & Semi-erect & Bipinnate & Pinnate & Creasing & Creasing \\
\hline CLN 4046 & Semi-erect & Semi-erect & Bipinnate & Bipinnate & Creasing & Creasing \\
\hline Kefaminano 4 & Semi-erect & Semi-erect & Pinnate & Bipinnate & Creasing & Creasing \\
\hline Bogor Cibanteng & Semi-erect & Semi-erect & Pinnate & Pinnate & Creasing & Creasing \\
\hline Kudamati 2 & Semi-erect & Semi-erect & Pinnate & Pinnate & Creasing & Creasing \\
\hline Gondol 2 & Semi-erect & Semi-erect & Bipinnate & Bipinnate & Creasing & Creasing \\
\hline Berlian & Semi-erect & Semi-erect & Pinnate & Pinnate & Creasing & Creasing \\
\hline Tanah Datar & Semi-erect & Semi-erect & Pinnate & Pinnate & Creasing & Creasing \\
\hline
\end{tabular}

Keterangan : $\quad$ M1= generasi ke-1 (M0 yang telah diberikan perlakuan irradiasi sinar gamma), M0= tanpa perlakuan irradiasi sinar gamma.

Letak petiole M1 memiliki tipe semi erect pada 20 genotipe. Keragaman tipe susunan bunga terdapat 3 genotipe memiliki susunan biparous atau susunan bunga ganda dan 17 genotipe memiliki susunan bunga uniporous atau susunan bunga tunggal. Tipe tangkai bunga juga terdapat perbedaan, yaitu terdapat 1 genotipe memiliki tipe tangkai bunga tanpa lapisan absisi atau absent, sedangkan 19 genotipe memiliki lapisan absisi pada tangkai bunga (Tabel 2).

Tabel 2. Keragaan karakter kualitatif letak petiole, tipe susunan bunga, dan tipe tangkai bunga 20 genotipe tomat M1 dan M0

\begin{tabular}{|c|c|c|c|c|c|c|}
\hline \multirow{2}{*}{ Genotipe } & \multicolumn{2}{|c|}{ Letak petiole } & \multicolumn{2}{|c|}{ Tipe susunan bunga } & \multicolumn{2}{|c|}{ Tipe tangkai bunga } \\
\hline & M1 & M0 & M1 & M0 & M1 & M0 \\
\hline Kudamati 1 & Semi-erect & Semi-erect & Uniparous & Uniparous & Present & Present \\
\hline Kefaminano 6 & Semi-erect & Horizontal & Uniparous & Uniparous & Present & Present \\
\hline Aceh 1 & Semi-erect & Semi-erect & Uniparous & Uniparous & Present & Present \\
\hline Lombok1 & Semi-erect & Semi-erect & Uniparous & Uniparous & Present & Present \\
\hline Aceh 5 & Semi-erect & Semi-erect & Uniparous & Uniparous & Present & Present \\
\hline Kemir & Semi-erect & Semi-erect & Uniparous & Uniparous & Present & Present \\
\hline Chung & Semi-erect & Semi-erect & Uniparous & Uniparous & Present & Present \\
\hline Jember & Semi-erect & Semi-erect & Biparous & Biparous & Present & Present \\
\hline Situbondo GL & Semi-erect & Semi-erect & Biparous & Uniparous & Present & Present \\
\hline Makassar3 & Semi-erect & Semi-erect & Uniparous & Uniparous & Present & Present \\
\hline Situbondo BK & Semi-erect & Semi-erect & Uniparous & Uniparous & Present & Present \\
\hline Lombok 3 & Semi-erect & Semi-erect & Uniparous & Uniparous & Present & Present \\
\hline Lombok 4 & Semi-erect & Semi-erect & Uniparous & Uniparous & Absent & Absent \\
\hline CLN 4046 & Semi-erect & Semi-erect & Uniparous & Uniparous & Present & Present \\
\hline Kefaminano 4 & Semi-erect & Horizontal & Uniparous & Biparous & Present & Present \\
\hline Bogor Cibanteng & Semi-erect & Semi-erect & Uniparous & Uniparous & Present & Present \\
\hline Kudamati 2 & Semi-erect & Semi-erect & Biparous & Biparous & Present & Present \\
\hline Gondol 2 & Semi-erect & Semi-erect & Uniparous & Uniparous & Present & Present \\
\hline Berlian & Semi-erect & Semi-erect & Uniparous & Uniparous & Present & Present \\
\hline Tanah Datar & Semi-erect & Semi-erect & Uniparous & Uniparous & Present & Present \\
\hline
\end{tabular}


Perubahan juga muncul pada karakter letak petiole dimana pada M0 genotipe Kefaminano 6 dan Kefaminano 4 memiliki arah horizontal, sedangkan pada M1 memiliki letak petiole semi-erect. Tanaman M0 genotipe Situbondo GL dan Kefaminano 4 memiliki tipe susunan bunga uniparous dan biparous, sedangkan pada tanaman M1 terjadi perubahan tipe susunan bunga dimana genotipe Situbondo GL memiliki bentuk biparous, dan genotipe Kefaminano 4 memiliki tipe susunan bunga uniparous. Tipe tangkai bunga pada M0 dan M1 tidak terdapat perbedaan (Tabel 2).
Sifat kualitatif pada karakter hasil. Pengamatan dilakukan pada buah tomat dengan perlakuan iradiasi 495 Gy. Secara umum pada dosis iradiasi 495 Gy keseluruhan genotipe memiliki karakter kualitatif yang berbeda-beda. Genotipe iradiasi sinar gamma 495 Gy Kudamati 1, Aceh 1, Aceh 5, Situbondo GL, Makassar 3, Lombok 3, Lombok 4, dan Kudamati 2 memiliki bentuk buah pipih pada. Genotipe Kefaminano 6, dan Tanah Datar memiliki bentuk buah elips, sedangkan genotipe Lombok 1, Kemir, Chung, Jember, Situbondo BK, Bogor Cibanteng, dan Berlian memiliki bentuk buah bulat. Bentuk buah genotipe CLN 4046 cordate, sedangkan Kefaminano 4 memiliki bentuk buah ovate (Gambar 1).
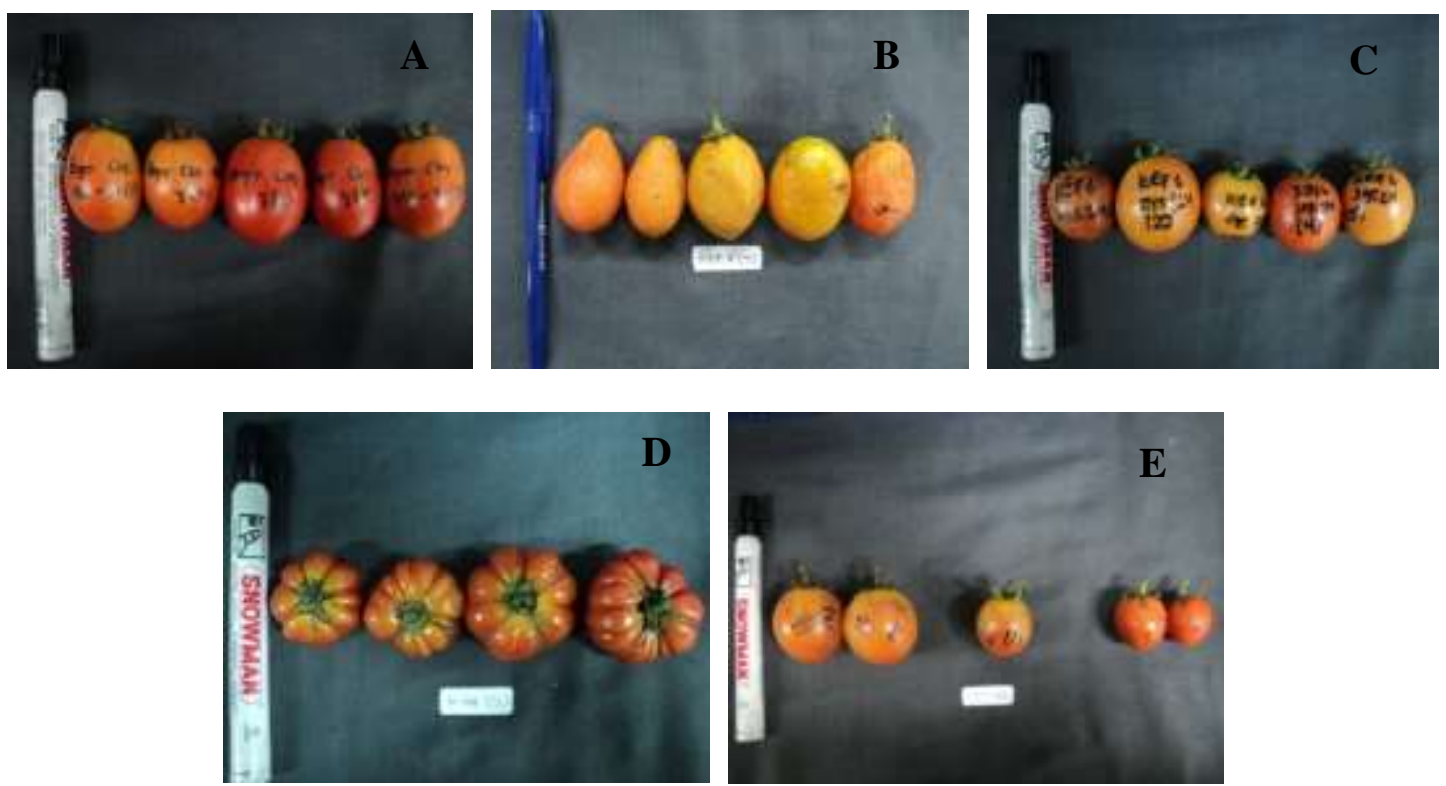

Gambar 1. Keragaan bentuk buah: A. Bogor Cibanteng (Bulat) B. Kefaminano 4 (Ovate) C. Kefaminano 6 (Elips) D. Kudamati 1 (Pipih) E. CLN 4046 (Cordate)

Variasi juga terdapat pada karakter ribbing atau lekukan pada perlakuan iradasi sinar gamma $495 \mathrm{~Gy}$, dimana 1 genotipe memiliki lekukan sangat kuat, 7 genotipe kuat, 1 genotipe lemah, dan 11 genotipe tidak ada lekukan. Karakter bentuk ujung buah juga tedapat keragaman yaitu terdapat 2 genotipe memiliki ujung buah melekuk, 6 genotipe melekuk agak datar, 7 genotipe datar, 3 genotipe datar meruncing, dan 2 genotipe memiliki ujung buah meruncing (Tabel 3).

Keragaman jumlah lokus pada tanaman iradiasi sinar gamma 495 Gy terdapat 6 genotipe memiliki dua jumlah lokus, 3 genotipe dua dan tiga lokus, 3 genotipe tiga dan empat lokus, 8 genotipe lebih dari enam lokus. Karakter diameter lokus juga terdapat keragaman yaitu 3 genotipe memiliki diameter sangat kecil, 8 genotipe kecil, 7 genotipe sedang, dan 2 genotipe memiliki diameter besar (Tabel 3).

Terdapat 10 genotipe memiliki warna buah merah, 6 genotipe merah cerah, 3 genotipe merah muda, dan 1 genotipe memiliki warna turning. Karakter cracking diamati untuk melihat ketahanan terhadap gejala pecah buah, terdapat 14 genotipe sangat tahan, dan 6 genotipe tahan terhadap pecah buah. Keragaman karakter kualitatif pasca panen pada tanaman tomat sejalan dengan penelitian Gumelar (2014) yaitu terdapat keragaman dalam karakter bentuk buah, irisan melintang, depresi ujung tangkai, bentuk ujung buah jumlah rongga buah, dan bahu hijau buah pada lima genotipe tomat (Tabel 3). 
Tabel 3. Keragaan karakter kualitatif pembentuk buah 20 genotipe tomat M1

\begin{tabular}{|c|c|c|c|c|c|c|c|}
\hline \multirow{2}{*}{ Genotipe } & \multicolumn{7}{|c|}{ Karakter } \\
\hline & $\mathrm{Bb}$ & $\mathrm{Rb}$ & $\mathrm{BUb}$ & JL & $\mathrm{DL}$ & WB & $\mathrm{Crc}$ \\
\hline Kudamati 1 & Pipih & Kuat & $\begin{array}{l}\text { Melekuk agak } \\
\text { datar }\end{array}$ & $>6$ & Sedang & Merah cerah & Sangat tahan \\
\hline Kefaminano 6 & Elips & $\begin{array}{l}\text { Tidak } \\
\text { Ada }\end{array}$ & Datar & 3 dan 4 & Kecil & Merah & Tahan \\
\hline Aceh 1 & Pipih & Kuat & Melekuk & $>6$ & Kecil & Merah cerah & Sangat tahan \\
\hline Lombok1 & Bulat & $\begin{array}{l}\text { Tidak } \\
\text { Ada }\end{array}$ & Meruncing & 2 & $\begin{array}{l}\text { Sangat } \\
\text { kecil }\end{array}$ & Merah cerah & Sangat tahan \\
\hline Aceh 5 & Pipih & Kuat & $\begin{array}{l}\text { Melekuk agak } \\
\text { datar }\end{array}$ & $>6$ & Sedang & Merah & Sangat tahan \\
\hline Kemir & Bulat & Tidak ada & Datar & 2 dan 3 & Kecil & Merah muda & Tahan \\
\hline Chung & Bulat & Tidak ada & Datar & 2 & $\begin{array}{l}\text { Sangat } \\
\text { kecil }\end{array}$ & Merah cerah & Sangat tahan \\
\hline Jember & Bulat & Tidak ada & $\begin{array}{l}\text { Datar } \\
\text { meruncing }\end{array}$ & 2 & Kecil & Merah & Sangat tahan \\
\hline Situbondo GL & Pipih & Kuat & $\begin{array}{l}\text { Meruncing } \\
\text { agak datar }\end{array}$ & $>6$ & Sedang & Merah & Tahan \\
\hline Makassar 3 & Pipih & Kuat & $\begin{array}{l}\text { Melekuk agak } \\
\text { data }\end{array}$ & $>6$ & Besar & Merah cerah & Sangat tahan \\
\hline Situbondo BK & Bulat & Tidak ada & Datar & 3 dan 4 & Kecil & Merah & Sangat tahan \\
\hline Lombok 3 & Pipih & $\begin{array}{l}\text { Sangat } \\
\text { kuat }\end{array}$ & $\begin{array}{l}\text { Melekuk agak } \\
\text { datar }\end{array}$ & $>6$ & Sedang & Merah & Sangat tahan \\
\hline Lombok 4 & Pipih & Tidak ada & Datar & 2 dan 3 & Sedang & Merah & Tahan \\
\hline CLN 4046 & Cordate & Tidak ada & Meruncing & 2 dan 3 & Kecil & Turning & Sangat tahan \\
\hline Kefaminano 4 & Ovate & Tidak ada & $\begin{array}{l}\text { Datar } \\
\text { meruncing }\end{array}$ & 2 & $\begin{array}{l}\text { Sangat } \\
\text { kecil }\end{array}$ & Merah muda & Sangat tahan \\
\hline $\begin{array}{l}\text { Bogor } \\
\text { Cibanteng }\end{array}$ & Bulat & Tidak ada & Datar & 2 & Kecil & Merah cerah & Tahan \\
\hline Kudamati 2 & Pipih & Kuat & $\begin{array}{l}\text { Melekuk agak } \\
\text { datar }\end{array}$ & $>6$ & sedang & Merah & Sangat tahan \\
\hline Gondol 2 & Pipih & Kuat & Melekuk & $>6$ & Sedang & Merah & Tahan \\
\hline Berlian & Bulat & Lemah & Datar & 3 dan 4 & Besar & Merah & Sangat tahan \\
\hline Tanah Datar & Elips & Tidak ada & $\begin{array}{l}\text { Datar } \\
\text { meruncing }\end{array}$ & 2 & Kecil & Merah muda & Sangat tahan \\
\hline
\end{tabular}

Keterangan: Bb: Bentuk buah, Rb: Ribbing atau lekukan, BUb: Bentuk ujung buah, JL: Jumlah lokus, DL: Diameter lokus, WB: Warna buah, Crc: Cracking atau retakan

Kualitatif pasca panen juga diamati pada tanaman kontrol atau tanpa iradiasi sinar gamma 0 Gy. Secara umum terdapat keragaman karakter kualitatif pasca panen pada tanaman kontrol dan perbedaan karakter dengan tanaman iradiasi sinar gamma 495 Gy. Karakter bentuk buah pada tanaman kontrol genotipe Gondol 2 memiliki bentuk agak pipih, Lombok 1 cordate, sedangkan pada iradiasi sinar gamma 495 Gy genotipe Gondol 2 memiliki bentuk buah pipih, dan genotipe Lombok 1 bentuk bulat. Karakter ribbing mengalami perubahan pada tanaman kontrol genotipe Kudamati 1, Aceh 1, Situbondo GL, Makassar 3 memiliki ribbing sangat kuat, pada genotipe Lombok 4 ribbing kuat. Genotipe Kudamati 1, Aceh 1, Situbondo GL, Makassar 3 pada tanaman iradisi dosis 495 Gy memiliki ribbing kuat, sedangkan Lombok 4 tanpa ribbing.
Perubahan juga terjadi pada karakter bentuk ujung buah genotipe Aceh 1, Lombok 4, Bogor Cibanteng, Berlian, Gondol 2 memiliki bentuk ujung buah melekuk agak datar pada tanaman kontrol. Hasil iradiasi dosis 495 Gy genotipe Aceh 1, dan Gondol 2 memiliki bentuk melekuk, sedangkan genotipe Lombok 4, Bogor Cibanteng, dan Berlian memiliki bentuk ujung buah datar.

Karakter jumlah lokus tanaman kontrol genotipe Kefaminano 6, CLN 4046 memiliki dua rongga lokus, pada genotipe Kemir, dan Berlian memiliki empat, lima, dan enam rongga lokus, sedangkan genotipe Lombok 4 lebih dari enam rongga lokus. Tanaman iradiasi dosis $495 \mathrm{~Gy}$ genotipe Kemir, Lombok 4, dan CLN 4046 memiliki dua dan tiga rongga lokus, sedangkan pada genotipe Kefaminano 6, dan Berlian tiga, dan empat rongga lokus. Genotipe Aceh 1, 
Situbondo GL tanaman kontrol memiliki diameter lokus besar, genotipe Berlian sangat besar, dan genotipe Lombok 1 kecil. Perubahan pada dosis 495 Gy genotipe Aceh
1 memiliki diameter lokus kecil, Situbondo GL berdiameter sedang, Berlian berdiameter besar, dan genotipe Lombok 1 memiliki diameter lokus sangat kecil (Tabel 4).

Tabel 4. Keragaan karakter kualitatif pasca panen 20 genotipe M0

\begin{tabular}{|c|c|c|c|c|c|c|c|}
\hline \multirow{2}{*}{ Genotipe } & \multicolumn{7}{|c|}{ Karakter } \\
\hline & $\mathrm{Bb}$ & $\mathrm{Rb}$ & $\mathrm{BUb}$ & $\mathrm{JL}$ & DL & WB & $\mathrm{Crc}$ \\
\hline Kudamati 1 & Pipih & Sangat kuat & $\begin{array}{l}\text { Melekuk agak } \\
\text { datar }\end{array}$ & $>6$ & Sedang & Merah & Sangat tahan \\
\hline Kefaminano 6 & Elips & Tidak ada & Datar & 2 & Kecil & Merah cerah & Sangat tahan \\
\hline Aceh 1 & Pipih & Sangat kuat & $\begin{array}{l}\text { Melekuk agak } \\
\text { datar }\end{array}$ & $>6$ & Besar & Merah & Sangat tahan \\
\hline Lombok1 & Cordate & Tidak ada & Meruncing & 2 & Kecil & Merah muda & Sangat tahan \\
\hline Aceh 5 & Pipih & Kuat & $\begin{array}{l}\text { Melekuk agak } \\
\text { datar }\end{array}$ & $>6$ & Sedang & Merah & Sangat tahan \\
\hline Kemir & Bulat & Tidak ada & Datar & $4,5,6$ & Kecil & Merah cerah & Sangat tahan \\
\hline Chung & Bulat & Tidak ada & Datar & 2 & $\begin{array}{l}\text { Sangat } \\
\text { kecil }\end{array}$ & Merah cerah & Sangat tahan \\
\hline Jember & Bulat & Tidak ada & $\begin{array}{l}\text { Datar } \\
\text { meruncing }\end{array}$ & 2 & Kecil & Merah & Sangat tahan \\
\hline Situbondo GL & Pipih & Sangat kuat & $\begin{array}{l}\text { Melekuk agak } \\
\text { datar }\end{array}$ & $>6$ & Besar & Merah & Sangat tahan \\
\hline Makassar3 & Pipih & Sangat kuat & $\begin{array}{l}\text { Melekuk agak } \\
\text { datar }\end{array}$ & $>6$ & Besar & Merah cerah & Sangat tahan \\
\hline Situbondo BK & Bulat & Tidak ada & Datar & 3 dan 4 & Kecil & Merah & Sangat tahan \\
\hline Lombok 3 & Pipih & Sangat kuat & $\begin{array}{l}\text { Melekuk agak } \\
\text { datar }\end{array}$ & $>6$ & Sedang & Merah & Sangat tahan \\
\hline Lombok 4 & Pipih & Kuat & $\begin{array}{l}\text { Melekuk agak } \\
\text { datar }\end{array}$ & $>6$ & Sedang & Merah & Sangat tahan \\
\hline CLN 4046 & Cordate & Tidak ada & Meruncing & 2 & Kecil & Turning & Sangat tahan \\
\hline Kefaminano 4 & $\begin{array}{l}\text { Bentuk } \\
\text { telur }\end{array}$ & Tidak ada & $\begin{array}{l}\text { Datar } \\
\text { meruncing }\end{array}$ & 2 & $\begin{array}{l}\text { Sangat } \\
\text { kecil }\end{array}$ & Merah muda & Sangat tahan \\
\hline Bogor Cibanteng & Bulat & Tidak ada & $\begin{array}{l}\text { Melekuk agak } \\
\text { datar }\end{array}$ & 2 & Kecil & Merah & Sangat tahan \\
\hline Kudamati 2 & Pipih & Kuat & $\begin{array}{l}\text { Melekuk agak } \\
\text { datar }\end{array}$ & $>6$ & Sedang & Merah & Sangat tahan \\
\hline Gondol 2 & $\begin{array}{l}\text { Agak } \\
\text { pipih }\end{array}$ & Kuat & $\begin{array}{l}\text { Melekuk agak } \\
\text { datar }\end{array}$ & $>6$ & Sedang & Merah & Sangat tahan \\
\hline Berlian & Bulat & Lemah & $\begin{array}{l}\text { Melekuk agak } \\
\text { datar }\end{array}$ & $4,5,6$ & $\begin{array}{l}\text { Sangat } \\
\text { besar }\end{array}$ & Merah muda & Sangat tahan \\
\hline Tanah Datar & Elips & Tidak ada & $\begin{array}{l}\text { Datar } \\
\text { meruncing }\end{array}$ & 2 & Kecil & Merah muda & Sangat tahan \\
\hline
\end{tabular}

Keterangan: Bb: Bentuk buah, Rb: Ribbing atau lekukan, BUb: Bentuk ujung buah, JL: Jumlah lokus, DL: Diameter lokus, WB: Warna buah, Crc: Cracking atau retakan

Tanaman kontrol genotipe Kudamati 1 , Aceh 1, dan Bogor Cibanteng memiliki warna buah merah, genotipe Kefaminano 6, dan Kemir merah cerah, sedangkan Lombok 1 dan Berlian merah muda. Perubahan warna buah iradiasi dosis 495 Gy pada genotipe Kudamati 1, Aceh 1, Bogor Cibanteng, dan Lombok 1 memiliki warna merah cerah, genotipe Kefaminano 6 dan Berlian merah, sedangkan genotipe Kemir memiliki warna buah merah muda (Tabel 4).

Karakter cracking atau retakan buah pada tanaman kontrol memiliki karakter sangat tahan pada 20 genotipe, sedangkan hasil iradiasi dosis 495 Gy pada genotipe Kefaminano 6, Kemir,
Situbondo GL, Lombok 4, 3ogor Cibanteng, dan Gondol 2 memiliki karakter tahan (Gambar 2).

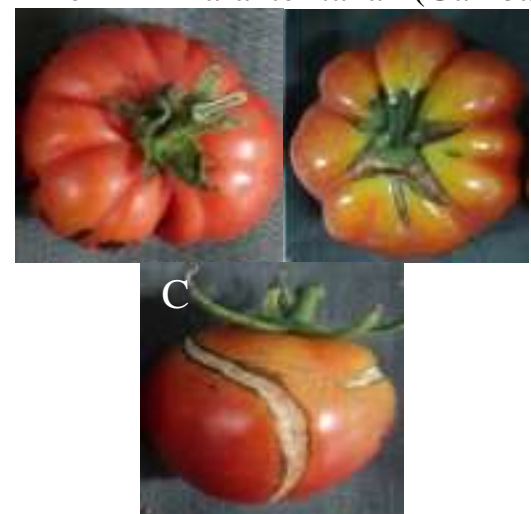


Gambar 2. Cracking pada buah: A. Sangat tahan $(0 \%)$ B. Tahan $(<25 \%)$ C. Mengalami pecah buah $(25 \% \leq 50 \%)$

\section{Sifat Kuantitatif}

Daya tumbuh. Perlakuan setiap genotipe M1 memberikan respon yang berbeda-beda sehingga berpengaruh pada perbedaan jumlah tanaman M1 yang ditransplanting di lapangan (Tabel 5).
Tanaman iradiasi genotipe Lombok 3, Kudamati 2, dan Gondol 2 memiliki persentase tanaman tertinggi (100\%), sedangkan pada tanaman kontrol persentase tanaman hidup genotipe Kudamati 2 rendah yaitu $45 \%$. Jumlah tanaman yang ditanam pada tanaman konrol memiliki jumlah yang sama pada setiap genotipe. Aceh 1, Situbondo BK, dan Gondol 2 memiliki persentase tanaman hidup tertinggi (100\%), dan persentase terendah genotipe Tanah Datar (10\%).

Tabel 5. Persentase tanaman hidup setelah aklimatisasi genotipe tomat M1 dan M0

\begin{tabular}{|c|c|c|c|c|c|c|}
\hline \multirow{2}{*}{ Genotipe } & \multicolumn{3}{|c|}{ M1 } & \multicolumn{3}{|c|}{ M0 } \\
\hline & Transplanting & Daya tumbuh & Persentase $(\%)$ & Transplanting & Daya tumbuh & Persentase $(\%)$ \\
\hline Kudamati 1 & 37 & 34 & 91.80 & 20 & 17 & 85 \\
\hline Kefaminano 6 & 50 & 38 & 76.00 & 20 & 19 & 95 \\
\hline Aceh 1 & 50 & 47 & 94.00 & 20 & 20 & 100 \\
\hline Lombok1 & 50 & 47 & 94.00 & 20 & 17 & 85 \\
\hline Aceh 5 & 30 & 26 & 86.60 & 20 & 14 & 70 \\
\hline Kemir & 16 & 15 & 93.75 & 20 & 17 & 85 \\
\hline Chung & 29 & 25 & 86.00 & 20 & 8 & 40 \\
\hline Jember & 38 & 29 & 76.32 & 20 & 14 & 70 \\
\hline Situbondo GL & 50 & 41 & 82.00 & 20 & 18 & 90 \\
\hline Makassar3 & 29 & 28 & 96.55 & 20 & 16 & 80 \\
\hline Situbondo BK & 38 & 32 & 84.00 & 20 & 20 & 100 \\
\hline Lombok 3 & 49 & 49 & 100.00 & 20 & 18 & 90 \\
\hline Lombok 4 & 50 & 46 & 92.00 & 20 & 17 & 85 \\
\hline CLN 4046 & 19 & 17 & 89.47 & 20 & 17 & 85 \\
\hline Kefaminano 4 & 50 & 47 & 94.00 & 20 & 15 & 75 \\
\hline Bogor Cibanteng & 19 & 15 & 78.90 & 20 & 18 & 90 \\
\hline Kudamati 2 & 37 & 37 & 100.00 & 20 & 9 & 45 \\
\hline Gondol 2 & 50 & 50 & 100.00 & 20 & 20 & 100 \\
\hline Berlian & 26 & 25 & 96.00 & 20 & 7 & 35 \\
\hline Tanah Datar & 42 & 28 & 66.67 & 20 & 2 & 10 \\
\hline
\end{tabular}

Umur berbunga. Penentuan umur berbunga sangat penting karena merupakan bagian dari karakter seleksi (Purwati, 2009). Umur berbunga tanaman tomat berkisar pada 2628 HST (Gumelar, 2014), sedangkan umur panen tomat dari tanam hingga masa panen berkisar 5065 HST (Jones, 2008). Pengamatan dilakukan saat tanaman telah berbunga $50 \%$ pada setiap genotipe. Berdasarkan data pengamatan umur berbunga tanaman iradiasi berkisar pada 20-28 HST, sedangkan pada tanaman kontrol 27-32 HST. Umur panen pada tanaman iradiasi berkisar 46-51 HST, dan tanaman kontrol 52-57 HST. Terdapat 12 genotipe iradiasi sinar gamma 495 Gy yang memiliki umur genjah dibandingkan tanaman kontrol yaitu genotipe Kudamati 1, Kefaminano 6, Aceh 1, Lombok 1, Kemir, Chung, Situbondo BK, Lombok 3, Lombok 4, CLN 4046, Bogor Cibanteng, dan Tanah datar (Tabel 6).
Tinggi tanaman. Karakter tinggi tanaman merupakan indikator paling umum yang digunakan untuk melihat dampak mutagen, baik fisik maupun kimia (Aisyah, 2006). Tabel 7 menunjukkan nilai tengah tertinggi dosis iradiasi 495 Gy terdapat pada genotipe Gondol 2 (145.72 $\mathrm{cm})$ dan terendah pada genotipe Chung (45.92 $\mathrm{cm})$. Keragaman tertinggi pada genotipe Jember $(48.11 \%)$, dan terendah pada genotipe Tanah Datar (7.64\%). Dosis 0 Gy atau tanaman kontrol nilai tengah tertinggi tinggi tanaman pada genotipe Makassar $3(130.82 \mathrm{~cm})$, dan terendah genotipe Kemir $(59.00 \mathrm{~cm})$. Keragaman tertinggi terdapat pada genotipe Jember $(48.11 \%)$, dan terendah genotipe Tanah Datar (7.64\%). 
Bul. Agrohorti 3(1): 1-16 (2015)

Tabel 6. Umur berbunga dan umur panen genotipe tomat M1 dan M0

\begin{tabular}{|c|c|c|c|c|}
\hline \multirow{2}{*}{ Genotipe } & \multicolumn{2}{|c|}{ M1 } & \multicolumn{2}{|c|}{ M0 } \\
\hline & Umur berbunga & Umur panen & Umur berbunga & Umur panen \\
\hline & \multicolumn{4}{|c|}{ 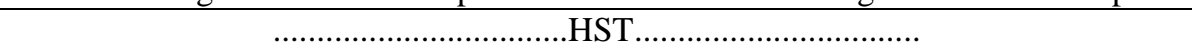 } \\
\hline Kudamati 1 & 28 & 46 & 32 & 52 \\
\hline Kefaminano 6 & 28 & 51 & 27 & 57 \\
\hline Aceh 1 & 20 & 51 & 32 & 52 \\
\hline Lombok1 & 20 & 51 & 32 & 52 \\
\hline Aceh 5 & 21 & 53 & 32 & 52 \\
\hline Kemir & 25 & 46 & 32 & 52 \\
\hline Chung & 28 & 46 & 27 & 50 \\
\hline Jember & 20 & 53 & 32 & 52 \\
\hline Situbondo GL & 20 & 58 & 27 & 57 \\
\hline Makassar3 & 28 & 58 & 27 & 57 \\
\hline Situbondo BK & 20 & 53 & 27 & 57 \\
\hline Lombok 3 & 20 & 46 & 27 & 57 \\
\hline Lombok 4 & 28 & 46 & 32 & 52 \\
\hline CLN 4046 & 21 & 51 & 32 & 52 \\
\hline Kefaminano 4 & 24 & 58 & 27 & 57 \\
\hline Bogor Cibanteng & 20 & 51 & 32 & 52 \\
\hline Kudamati 2 & 20 & 58 & 32 & 52 \\
\hline Gondol 2 & 20 & 58 & 27 & 57 \\
\hline Berlian & 21 & 58 & 27 & 50 \\
\hline Tanah Datar & 22 & 46 & 27 & 52 \\
\hline
\end{tabular}

Tabel 7. Nilai tengah, simpangan baku, dan koefisien keragaman tinggi genotipe tomat M1 dan M0

\begin{tabular}{|c|c|c|c|c|}
\hline \multirow{2}{*}{ Genotipe } & \multicolumn{2}{|l|}{ M1 } & \multicolumn{2}{|c|}{ M0 } \\
\hline & $\bar{x} \pm \alpha(\mathrm{cm})$ & $\mathrm{KK}(\%)$ & $\bar{x} \pm \alpha(\mathrm{cm})$ & $\mathrm{KK}(\%)$ \\
\hline Kudamati 1 & $111.75 \pm 21.32$ & 19.08 & $113.86 \pm 14.68$ & 12.89 \\
\hline Kefaminano6 & $63.38 \pm 12.08$ & 17.66 & $72.13 \pm 8.01$ & 11.10 \\
\hline Aceh 1 & $77.13 \pm 28.05$ & 36.37 & $126.00 \pm 22.63$ & 17.96 \\
\hline Lombok1 & $88.57 \pm 15.04$ & 16.99 & $74.50 \pm 12.04$ & 16.16 \\
\hline Aceh 5 & $71.38 \pm 14.32$ & 20.07 & $106.00 \pm 14.86$ & 14.02 \\
\hline Kemir & $63.86 \pm 15.15$ & 23.72 & $59.00 \pm 12.94$ & 21.94 \\
\hline Chung & $45.92 \pm 11.65$ & 25.37 & $71.33 \pm 11.15$ & 15.63 \\
\hline Jember & $64.00 \pm 46.67$ & 48.11 & $80.50 \pm 4.04$ & 5.02 \\
\hline Situbondo GL & $120.65 \pm 26.30$ & 21.80 & $119.29 \pm 13.96$ & 11.70 \\
\hline Makassar3 & $127.43 \pm 15.65$ & 12.28 & $130.82 \pm 13.27$ & 10.14 \\
\hline Situbondo BK & $60.00 \pm 5.66$ & 9.43 & $64.00 \pm 6.08$ & 9.50 \\
\hline Lombok 3 & $126.31 \pm 17.24$ & 13.65 & $113.50 \pm 14.85$ & 13.08 \\
\hline Lombok 4 & $108.26 \pm 26.35$ & 24.34 & $119.00 \pm 24.88$ & 20.91 \\
\hline CLN 4046 & $74.83 \pm 14.20$ & 18.97 & $68.50 \pm 2.12$ & 3.10 \\
\hline Kefaminano 4 & $74.07 \pm 18.54$ & 25.03 & $65.20 \pm 11.12$ & 17.06 \\
\hline Bogor Cibanteng & $60.14 \pm 15.25$ & 25.35 & $78.33 \pm 12.66$ & 16.16 \\
\hline Kudamati 2 & $77.21 \pm 31.10$ & 40.28 & $72.20 \pm 9.04$ & 12.52 \\
\hline Gondol 2 & $145.72 \pm 35.55$ & 24.39 & $105.54 \pm 14.30$ & 13.55 \\
\hline Berlian & $57.21 \pm 5.13$ & 8.97 & $66.50 \pm 3.54$ & 5.32 \\
\hline Tanah Datar & $84.50 \pm 6.45$ & 7.64 & $113.50 \pm 6.36$ & 5.61 \\
\hline
\end{tabular}

Diameter batang. Nilai tengah tertinggi pada diameter batang dosis iradiasi 495 Gy pada genotipe Gondol $2(3.56 \mathrm{~cm})$, dan terendah pada genotipe Berlian $(0.64 \mathrm{~cm})$ (Tabel 8). Nilai tengah tertinggi tanaman kontrol tanpa iradiasi terdapat pada genotipe Kudamati $1(0.92 \mathrm{~cm})$, sedangkan terendah genotipe Jember $(0.60 \mathrm{~cm})$.

Keragaman tertinggi dosis iradiasi 495 Gy terdapat pada genotipe Jember (35.36\%), dan terendah Gondol $2(13.71 \%)$. Keragaman tertinggi tanaman kontrol genotipe Jember (41.94\%), 
Bul. Agrohorti 3(1): 1-16 (2015)

sedangkan terendah terdapat pada genotipe Makassar $3(6.38 \%)$.

Tabel 8. Nilai tengah, simpangan baku, dan koefisien keragaman diameter batang genotipe tomat M1 dan M0

\begin{tabular}{lcccr}
\hline \multirow{2}{*}{ Genotipe } & \multicolumn{2}{c}{ M1 } & \multicolumn{2}{c}{ M0 } \\
\cline { 2 - 5 } \multicolumn{1}{c}{$\bar{x} \pm \alpha(\mathrm{cm})$} & KK $(\%)$ & $\bar{x} \pm \alpha(\mathrm{cm})$ & KK (\%) \\
\hline Kudamati 1 & $1.03 \pm 0.22$ & 21.80 & $0.92 \pm 0.18$ & 19.59 \\
Kefaminano6 & $0.74 \pm 0.21$ & 27.97 & $0.80 \pm 0.20$ & 25.00 \\
Aceh 1 & $0.79 \pm 0.21$ & 26.83 & $0.85 \pm 0.21$ & 24.96 \\
Lombok1 & $0.93 \pm 0.21$ & 22.31 & $0.50 \pm 0.10$ & 20.00 \\
Aceh 5 & $0.89 \pm 0.28$ & 32.09 & $0.90 \pm 0.18$ & 19.70 \\
Kemir & $0.81 \pm 0.14$ & 17.37 & $0.80 \pm 0.10$ & 12.50 \\
Chung & $0.69 \pm 0.11$ & 16.68 & $0.65 \pm 0.07$ & 10.88 \\
Jember & $0.80 \pm 0.28$ & 35.36 & $0.60 \pm 0.25$ & 41.94 \\
Situbondo GL & $1.04 \pm 0.17$ & 15.89 & $0.91 \pm 0.24$ & 15.89 \\
Makassar3 & $1.08 \pm 0.16$ & 14.32 & $0.73 \pm 0.05$ & 6.38 \\
Situbondo BK & $0.70 \pm 0.10$ & 14.29 & $0.73 \pm 0.11$ & 14.63 \\
Lombok 3 & $0.96 \pm 0.19$ & 19.73 & $0.55 \pm 0.07$ & 12.86 \\
Lombok 4 & $3.53 \pm 0.73$ & 20.60 & $0.73 \pm 0.11$ & 14.63 \\
CLN 4046 & $2.56 \pm 0.55$ & 21.44 & $0.90 \pm 0.14$ & 15.71 \\
Kefaminano 4 & $3.15 \pm 0.40$ & 12.78 & $0.80 \pm 0.14$ & 17.68 \\
Bogor Cibanteng & $0.72 \pm 0.25$ & 34.57 & $0.70 \pm 0.28$ & 40.41 \\
Kudamati 2 & $3.14 \pm 0.79$ & 25.27 & $0.78 \pm 0.19$ & 24.66 \\
Gondol 2 & $3.56 \pm 0.49$ & 13.71 & $0.79 \pm 0.08$ & 10.51 \\
Berlian & $0.64 \pm 0.19$ & 29.81 & $0.75 \pm 0.07$ & 9.43 \\
Tanah Datar & $0.70 \pm 0.10$ & 14.29 & $0.75 \pm 0.07$ & 9.43 \\
\hline Kerangary
\end{tabular}

Keterangan : $\quad$ M1 = generasi ke-1 (M0 yang telah diberikan perlakuan irradiasi sinar gamma), M0= tanpa perlakuan irradiasi sinar gamma.

Jumlah cabang utama. Pengamatan jumlah cabang utama dilakukan pada saat pertumbuhan vegetatif telah mencapai maksimum. Nilai tengah tertinggi pada dosis iradiasi 495 Gy genotipe Lombok 3 (2.25), dan terendah terdapat pada genotipe Kemir (1.14). Keragaman tertinggi pada genotipe Jember $(47.14 \%)$, dan terendah genotipe Kefaminano 6 (17.87\%).

Tabel 9. Nilai tengah, simpangan baku, dan koefisien keragaman jumlah cabang utama genotipe tomat M1 dan M0

\begin{tabular}{|c|c|c|c|c|}
\hline \multirow{2}{*}{ Genotipe } & \multicolumn{2}{|c|}{ M1 } & \multicolumn{2}{|c|}{ M0 } \\
\hline & $\bar{x} \pm \alpha$ & $\mathrm{KK}(\%)$ & $\bar{x} \pm \alpha$ & $\mathrm{KK}(\%)$ \\
\hline Kudamati 1 & $2.08 \pm 0.55$ & 26.23 & $2.07 \pm 0.27$ & 12.90 \\
\hline Kefaminano6 & $2.09 \pm 0.37$ & 17.87 & $1.00 \pm 0.00$ & 0.00 \\
\hline Aceh 1 & $1.58 \pm 0.70$ & 44.64 & $2.00 \pm 0.00$ & 0.00 \\
\hline Lombok1 & $1.34 \pm 0.52$ & 38.56 & $1.00 \pm 0.00$ & 0.00 \\
\hline Aceh 5 & $1.56 \pm 0.50$ & 31.75 & $1.70 \pm 0.21$ & 28.41 \\
\hline Kemir & $1.14 \pm 0.31$ & 27.50 & $1.89 \pm 0.33$ & 17.65 \\
\hline Chung & $1.33 \pm 0.58$ & 43.30 & $2.00 \pm 0.00$ & 0.00 \\
\hline Jember & $1.50 \pm 0.71$ & 47.14 & $1.00 \pm 0.58$ & 57.74 \\
\hline Situbondo GL & $1.95 \pm 0.50$ & 25.51 & $2.00 \pm 0.00$ & 0.00 \\
\hline Makassar3 & $2.22 \pm 0.59$ & 26.45 & $2.00 \pm 0.00$ & 0.00 \\
\hline Situbondo BK & $1.50 \pm 0.50$ & 33.33 & $1.00 \pm 0.00$ & 0.00 \\
\hline Lombok 3 & $2.25 \pm 0.48$ & 21.28 & $2.00 \pm 0.00$ & 0.00 \\
\hline Lombok 4 & $2.00 \pm 0.63$ & 31.62 & $1.00 \pm 0.00$ & 0.00 \\
\hline CLN 4046 & $1.33 \pm 0.47$ & 35.36 & $2.00 \pm 0.00$ & 0.00 \\
\hline Kefaminano 4 & $1.40 \pm 0.49$ & 34.99 & $1.00 \pm 0.00$ & 0.00 \\
\hline Bogor Cibanteng & $1.83 \pm 0.37$ & 20.33 & $2.00 \pm 0.00$ & 0.00 \\
\hline Kudamati 2 & $1.71 \pm 0.59$ & 34.36 & $2.00 \pm 0.00$ & 0.00 \\
\hline Gondol 2 & $1.92 \pm 0.44$ & 22.92 & $1.92 \pm 0.28$ & 14.42 \\
\hline Berlian & $1.43 \pm 0.49$ & 34.64 & $2.00 \pm 0.00$ & 0.00 \\
\hline Tanah Datar & $1.75 \pm 0.43$ & 24.74 & $1.00 \pm 0.00$ & 0.00 \\
\hline
\end{tabular}


Jumlah cabang utama pada tanaman kontrol memiliki nilai tengah tertinggi pada genotipe Kudamati 1 (2.07), dan terendah pada genotipe Tanah Datar, Kefaminano 6, Lombok 1, Situbondo BK, Lombok 4, dan Kefaminano 4 (1.00). Keragaman tertinggi terdapat pada genotipe Jember (57.74\%), sedangkan terendah terdapat pada 15 genotipe $(0.00 \%)$, dimana genotipe tersebut telah memiliki jumlah cabang utama yang seragam (Tabel 9).
Diameter buah. Kudamati 1 pada dosisi 495 Gy memiliki diameter buah tertinggi yaitu $37.96 \mathrm{~mm}$, sedangkan Chung memiliki diameter terendah yaitu $15.86 \mathrm{~mm}$. Nilai koefisien keragaman tertinggi terdapat pada genotipe Makassar 3 (29.98\%), dan terendah Tanah Datar $(13.95 \%)$.

Tabel 10. Nilai tengah, simpangan baku, dan koefisien keragaman diameter buah genotipe tomat M1 dan M0

\begin{tabular}{|c|c|c|c|c|}
\hline \multirow{2}{*}{ Genotipe } & \multicolumn{2}{|c|}{ M1 } & \multicolumn{2}{|c|}{ M0 } \\
\hline & $\bar{x} \pm \alpha(\mathrm{mm})$ & KK $(\%)$ & $\bar{x} \pm \alpha(\mathrm{mm})$ & KK $(\%)$ \\
\hline Kudamati 1 & $37.96 \pm 7.02$ & 18.48 & $37.00 \pm 1.73$ & 4.68 \\
\hline Kefaminano6 & $32.87 \pm 5.23$ & 15.91 & $24.50 \pm 2.12$ & 8.66 \\
\hline Aceh 1 & $31.61 \pm 7.45$ & 23.56 & $37.67 \pm 1.53$ & 4.06 \\
\hline Lombok1 & $28.76 \pm 5.32$ & 18.51 & $25.33 \pm 0.58$ & 2.28 \\
\hline Aceh 5 & $32.92 \pm 7.06$ & 21.45 & $23.67 \pm 0.58$ & 2.44 \\
\hline Kemir & $30.40 \pm 7.58$ & 24.92 & $33.00 \pm 1.73$ & 5.25 \\
\hline Chung & $15.86 \pm 2.75$ & 17.35 & $18.33 \pm 0.58$ & 3.15 \\
\hline Jember & $25.95 \pm 4.00$ & 15.42 & $26.33 \pm 1.53$ & 5.80 \\
\hline Situbondo GL & $27.75 \pm 5.24$ & 18.89 & $39.50 \pm 4.95$ & 12.53 \\
\hline Makassar3 & $30.47 \pm 9.13$ & 29.98 & $34.33 \pm 1.53$ & 4.45 \\
\hline Situbondo BK & $29.17 \pm 6.37$ & 21.84 & $28.33 \pm 2.08$ & 7.35 \\
\hline Lombok 3 & $31.29 \pm 7.59$ & 24.25 & $41.00 \pm 1.73$ & 4.22 \\
\hline Lombok 4 & $28.32 \pm 6.82$ & 24.07 & $30.33 \pm 1.53$ & 5.04 \\
\hline CLN 4046 & $25.96 \pm 4.42$ & 17.04 & $22.67 \pm 1.53$ & 6.74 \\
\hline Kefaminano 4 & $35.10 \pm 6.60$ & 18.81 & $27.00 \pm 1.73$ & 6.42 \\
\hline Bogor Cibanteng & $30.68 \pm 8.12$ & 26.48 & $35.67 \pm 1.15$ & 3.24 \\
\hline Kudamati 2 & $35.56 \pm 5.22$ & 14.67 & $30.33 \pm 1.53$ & 5.04 \\
\hline Gondol 2 & $31.56 \pm 5.51$ & 17.46 & $41.33 \pm 4.62$ & 11.17 \\
\hline Berlian & $30.33 \pm 4.47$ & 14.74 & $35.00 \pm 2.83$ & 8.08 \\
\hline Tanah Datar & $29.33 \pm 4.09$ & 13.95 & $29.67 \pm 3.21$ & 10.84 \\
\hline
\end{tabular}

Diameter buah tertinggi pada tanaman kontrol yaitu genotipe Gondol 2 dengan nilai tengah $41.33 \mathrm{~mm}$, sedangkan terendah Chung $18.33 \mathrm{~mm}$. Nilai koefisien keragaman tertinggi Situbondo GL (12.53\%), sedangkan keragaman terendah Lombok 1 (2.28\%) (Tabel 10).

Panjang pedisel. Panjang pedisel diamati pada tiga buah tomat pada semua tanaman setiap genotipe. Nilai tengah tertinggi pada dosis $495 \mathrm{~Gy}$ yaitu genotipe Kefaminano 4 dengan nilai 8.67 $\mathrm{mm}$, dan terendah Kemir $4.20 \mathrm{~mm}$. Koefisien keragaman tertinggi pada genotipe Lombok 1 $(79.18 \%)$, sedangkan terendah genotipe Jember $(8.15 \%)$. Karakter panjang pedisel juga diamati pada tanaman kontrol. Genotipe Kefaminano 4 memiliki nilai tengah tertinggi yaitu $11.00 \mathrm{~mm}$, dan terendah Kefaminano 6 dengan nilai tengah $5.00 \mathrm{~mm}$. Koefisien keragaman tertinggi Kefaminano 6 (28.28\%), sedangkan keragaman terendah Aceh 5 (6.66\%).
Bobot buah. Bobot buah tertinggi M1 terdapat pada genotipe Bogor Cibanteng dengan nillai tengah $21.90 \mathrm{~g}$, dan terendah Chung $2.10 \mathrm{~g}$. Keragaman tertinggi juga terdapat pada genotipe Bogor Cibanteng (63.99\%), sedangkan terendah Kudamati 2 (29.05\%).

Nilai tengah tertinggi tanaman kontrol terdapat pada genotipe Aceh 1 yaitu $30.53 \mathrm{~g}$, dan terendah Chung 3.73 g. Genotipe Kefaminano 4 memiliki koefisien keragaman tertinggi (38.90\%), sedangkan terendah genotipe Kudamati 2 (1.32\%) (Tabel 12).

Koefisien keragaman genotipe Berlian tanaman kontrol (37.03\%), lebih tinggi dibandingkan M1 (34.90\%). Hal tersebut diduga pengambilan tanaman contoh pada bobot buah yang dilakukan secara acak mengakibatkan bobot buah pada tanaman contoh memiliki selisih yang besar, sehingga nilai koefisien keragaman menjadi tinggi. 
Tabel 11. Nilai tengah, simpangan baku, dan koefisien keragaman panjang pedisel genotipe tomat M1 dan M0

\begin{tabular}{lccrc}
\hline \multirow{2}{*}{ Genotipe } & \multicolumn{2}{c}{ M1 } & \multicolumn{2}{c}{ M0 } \\
\cline { 2 - 5 } \multicolumn{1}{c}{$\bar{x} \pm \alpha(\mathrm{mm})$} & $\mathrm{KK}(\%)$ & $\bar{x} \pm \alpha(\mathrm{mm})$ & KK $(\%)$ \\
\hline Kudamati 1 & $6.83 \pm 1.13$ & 16.52 & $9.50 \pm 0.71$ & 7.94 \\
Kefaminano6 & $6.70 \pm 1.46$ & 21.84 & $5.00 \pm 1.41$ & 28.28 \\
Aceh 1 & $6.54 \pm 1.50$ & 22.92 & $7.67 \pm 0.58$ & 7.53 \\
Lombok1 & $8.62 \pm 6.83$ & 79.18 & $8.33 \pm 0.58$ & 6.93 \\
Aceh 5 & $5.94 \pm 1.62$ & 27.26 & $8.67 \pm 0.58$ & 6.66 \\
Kemir & $4.20 \pm 1.61$ & 38.39 & $7.33 \pm 0.58$ & 7.87 \\
Chung & $6.05 \pm 1.41$ & 23.35 & $6.67 \pm 0.58$ & 8.66 \\
Jember & $6.33 \pm 0.52$ & 8.15 & $10.50 \pm 0.71$ & 6.73 \\
Situbondo GL & $6.92 \pm 1.31$ & 18.96 & $8.33 \pm 1.15$ & 13.86 \\
Makassar3 & $6.73 \pm 1.16$ & 17.27 & $7.67 \pm 0.58$ & 7.53 \\
Situbondo BK & $6.17 \pm 1.17$ & 18.96 & $6.67 \pm 0.58$ & 8.66 \\
Lombok 3 & $7.35 \pm 0.86$ & 11.72 & $7.50 \pm 0.71$ & 9.43 \\
Lombok 4 & $5.87 \pm 1.61$ & 19.78 & $7.33 \pm 0.58$ & 7.87 \\
CLN 4046 & $4.94 \pm 1.80$ & 36.36 & $6.33 \pm 0.58$ & 9.12 \\
Kefaminano 4 & $8.67 \pm 3.01$ & 34.68 & $11.00 \pm 1.00$ & 9.09 \\
Bogor Cibanteng & $6.00 \pm 1.67$ & 27.89 & $7.00 \pm 1.00$ & 14.29 \\
Kudamati 2 & $7.78 \pm 3.14$ & 40.31 & $6.67 \pm 0.58$ & 8.66 \\
Gondol 2 & $7.20 \pm 1.07$ & 14.80 & $8.00 \pm 1.00$ & 12.50 \\
Berlian & $6.44 \pm 1.13$ & 17.54 & $7.33 \pm 1.15$ & 15.75 \\
Tanah Datar & $6.00 \pm 2.96$ & 49.30 & $6.33 \pm 0.58$ & 9.12 \\
\hline Ken
\end{tabular}

Keterangan : $\quad$ M1 = generasi ke-1 (M0 yang telah diberikan perlakuan irradiasi sinar gamma), M0= tanpa perlakuan irradiasi sinar gamma.

Tabel 12. Nilai tengah, simpangan baku, dan koefisien keragaman bobot buah genotipe tomat M1 dan M0

\begin{tabular}{lcccc}
\hline \multirow{2}{*}{ Genotipe } & \multicolumn{2}{c}{ M1 } & \multicolumn{2}{c}{ M0 } \\
\cline { 2 - 5 } & $\bar{x} \pm \alpha(\mathrm{g})$ & $\mathrm{KK}(\%)$ & $14.67 \pm 1.53$ & KK $(\%)$ \\
\hline Kudamati 1 & $22.11 \pm 7.22$ & 32.63 & $29.00 \pm 9.85$ & 33.96 \\
Kefaminano6 & $25.63 \pm 9.55$ & 37.27 & $30.53 \pm 3.15$ & 10.33 \\
Aceh 1 & $16.32 \pm 8.81$ & 53.97 & $20.05 \pm 7.30$ & 36.38 \\
Lombok1 & $16.05 \pm 8.25$ & 51.37 & $10.31 \pm 0.25$ & 2.40 \\
Aceh 5 & $20.72 \pm 11.24$ & 54.24 & $24.67 \pm 4.04$ & 16.38 \\
Kemir & $17.80 \pm 10.96$ & 61.59 & $3.73 \pm 0.46$ & 12.35 \\
Chung & $2.10 \pm 1.02$ & 48.55 & $26.19 \pm 8.93$ & 3.40 \\
Jember & $19.33 \pm 6.09$ & 31.49 & $8.82 \pm 2.81$ & 31.85 \\
Situbondo GL & $10.75 \pm 3.55$ & 32.99 & $25.89 \pm 10.82$ & 41.81 \\
Makassar3 & $15.05 \pm 6.99$ & 46.49 & $21.16 \pm 11.65$ & 53.80 \\
Situbondo BK & $15.67 \pm 6.74$ & 43.04 & $24.98 \pm 3.74$ & 14.96 \\
Lombok 3 & $12.80 \pm 6.60$ & 51.56 & $11.17 \pm 3.12$ & 27.93 \\
Lombok 4 & $9.55 \pm 5.02$ & 52.60 & $18.49 \pm 7.02$ & 30.73 \\
CLN 4046 & $10.94 \pm 5.30$ & 48.40 & $15.05 \pm 4.89$ & 38.90 \\
Kefaminano 4 & $18.28 \pm 7.74$ & 42.36 & $10.74 \pm 0.14$ & 1.32 \\
Bogor Cibanteng & $21.90 \pm 14.02$ & 63.99 & $21.43 \pm 4.28$ & 19.98 \\
Kudamati 2 & $21.66 \pm 6.29$ & 29.05 & $20.41 \pm 5.27$ & 25.03 \\
Gondol 2 & $12.89 \pm 5.39$ & 41.80 & & \\
Berlian & $19.08 \pm 6.66$ & 34.90 & 39.06 & \\
Tanah Datar & $18.93 \pm 7.39$ & &
\end{tabular}

Panjang buah. Karakter panjang buah dengan nilai tengah tertinggi pada 495 Gy yaitu Kefaminano 6 dengan nilai $38.68 \mathrm{~mm}$, dan terendah Chung $14.58 \mathrm{~mm}$. Tanah Datar memiliki keragaman tertinggi $(27.34 \%)$, sedangkan
Kudamati 2 memiliki keragaman terendah (9.44\%).

Tanaman kontrol genotipe Kefaminano 4 memiliki panjang buah tertinggi dengan nilai tengaj $44.67 \mathrm{~mm}$, dan Kudamati 1 memiliki 
panjang buah terendah yaitu $15.33 \mathrm{~mm}$. Koefisien

Kefaminano 6 (15.71\%), sedangkan Tanah Datar keragaman tertinggi terdapat pada genotipe memiliki keragaman terendah $(1.57 \%)$.

Tabel 13. Nilai tengah, simpangan baku, dan koefisien keragaman panjang buah genotipe tomat M1 dan M0

\begin{tabular}{|c|c|c|c|c|}
\hline \multirow{2}{*}{ Genotipe } & \multicolumn{2}{|c|}{ M1 } & \multicolumn{2}{|c|}{ M0 } \\
\hline & $\bar{x} \pm \alpha(\mathrm{mm})$ & KK (\%) & $\bar{x} \pm \alpha(\mathrm{mm})$ & KK (\%) \\
\hline Kudamati 1 & $23.50 \pm 4.26$ & 18.14 & $15.33 \pm 2.52$ & 16.41 \\
\hline Kefaminano6 & $38.68 \pm 5.83$ & 15.08 & $22.50 \pm 3.54$ & 15.71 \\
\hline Aceh 1 & $27.36 \pm 5.53$ & 20.20 & $20.33 \pm 1.15$ & 5.68 \\
\hline Lombok1 & $32.72 \pm 7.33$ & 22.39 & $37.00 \pm 3.46$ & 9.36 \\
\hline Aceh 5 & $31.97 \pm 5.87$ & 18.37 & $25.33 \pm 0.58$ & 2.28 \\
\hline Kemir & $29.07 \pm 5.19$ & 17.85 & $32.67 \pm 2.31$ & 7.07 \\
\hline Chung & $14.58 \pm 2.70$ & 18.52 & $17.00 \pm 1.00$ & 5.88 \\
\hline Jember & $31.87 \pm 6.75$ & 21.19 & $27.00 \pm 3.61$ & 13.35 \\
\hline Situbondo GL & $22.00 \pm 3.98$ & 18.08 & $23.00 \pm 2.65$ & 11.50 \\
\hline Makassar3 & $22.60 \pm 3.33$ & 14.75 & $24.00 \pm 1.00$ & 4.17 \\
\hline Situbondo BK & $23.17 \pm 4.40$ & 19.00 & $30.00 \pm 2.00$ & 6.67 \\
\hline Lombok 3 & $19.76 \pm 4.75$ & 24.03 & $24.33 \pm 1.53$ & 6.28 \\
\hline Lombok 4 & $17.83 \pm 3.85$ & 21.60 & $28.33 \pm 1.53$ & 5.39 \\
\hline CLN 4046 & $26.72 \pm 5.19$ & 19.43 & $33.00 \pm 2.65$ & 8.02 \\
\hline Kefaminano 4 & $27.86 \pm 8.31$ & 29.85 & $44.67 \pm 6.35$ & 14.22 \\
\hline Bogor Cibanteng & $34.77 \pm 8.86$ & 25.47 & $25.33 \pm 0.58$ & 2.28 \\
\hline Kudamati 2 & $22.17 \pm 2.09$ & 9.44 & $26.00 \pm 1.73$ & 6.66 \\
\hline Gondol 2 & $20.02 \pm 3.35$ & 16.75 & $22.67 \pm 1.53$ & 6.74 \\
\hline Berlian & $35.22 \pm 3.35$ & 9.50 & $26.00 \pm 1.00$ & 3.85 \\
\hline Tanah Datar & $28.33 \pm 7.75$ & 27.34 & $36.67 \pm 0.58$ & 1.57 \\
\hline
\end{tabular}

Keterangan : M1= generasi ke-1 (M0 yang telah diberikan perlakuan irradiasi sinar gamma), M0= tanpa perlakuan irradiasi sinar gamma.

Kekerasan buah. Gumelar (2015) menyatakan semakin rendah nilai kekerasan buah maka buah tersebut semakin keras begitu pula sebaliknya. Genotipe Situbondo GL memiliki nilai tertinggi $\left(87.83 \mathrm{~mm}^{2} 0 \mathrm{~g} \mathrm{~g}^{-1} 5 \mathrm{~s}^{-1}\right)$ artinya lunak, sedangkan Lombok 4 memiliki nilai terendah $\left(42.95 \mathrm{~mm} 50 \mathrm{~g}^{-1} 5 \mathrm{~s}^{-1}\right)$ artinya keras. Keragaman tertinggi dimiliki oleh Kefaminano 4
(47.96\%) dan terendah Lombok 4 (22.39\%). Genotipe Jember pada tanaman kontrol memiliki buah lunak dengan nilai kekerasan buah terendah $\left(37.78 \quad \mathrm{~mm} \quad 50 \quad \mathrm{~g}^{-1} \quad 5 \quad \mathrm{~s}^{-1}\right)$, sedangkan Kemir memiliki buah keras dengan nilai kekerasan buah tertinggi (77.78 mm $\left.50 \mathrm{~g} \mathrm{~g}^{-1} 5 \mathrm{~s}^{-1}\right)$. Nilai koefisien keragaman tertinggi terdapat pada Kemir (29.22\%), dan terendah Lombok 1 (11.70\%).

Tabel 14. Nilai tengah, simpangan baku, dan koefisien keragaman kekerasan buah genotipe tomat M1 dan M0

\begin{tabular}{|c|c|c|c|c|}
\hline \multirow[b]{2}{*}{ Genotipe } & \multicolumn{2}{|c|}{ M1 } & \multicolumn{2}{|c|}{ M0 } \\
\hline & $\begin{array}{c}\bar{x} \pm \alpha \\
\left(\mathrm{mm} 50 \mathrm{~g}^{-1} 5 \mathrm{~s}^{-1}\right)\end{array}$ & $\mathrm{KK}(\%)$ & $\begin{array}{c}\bar{x} \pm \alpha \\
\left(\mathrm{mm} 50 \mathrm{~g}^{-1} 5 \mathrm{~s}^{-1}\right)\end{array}$ & $\mathrm{KK}(\%)$ \\
\hline Kudamati 1 & $70.61 \pm 30.82$ & 43.65 & $66.78 \pm 13.97$ & 20.92 \\
\hline Kefaminano 6 & $57.24 \pm 19.51$ & 34.07 & $42.89 \pm 7.99$ & 18.63 \\
\hline Aceh 1 & $58.83 \pm 26.08$ & 44.33 & $61.00 \pm 10.20$ & 16.72 \\
\hline Lombok1 & $45.72 \pm 15.74$ & 34.42 & $59.56 \pm 6.97$ & 11.70 \\
\hline Aceh 5 & $52.47 \pm 24.60$ & 46.88 & $51.11 \pm 7.66$ & 14.98 \\
\hline Kemir & $79.22 \pm 23.35$ & 29.47 & $77.78 \pm 22.73$ & 29.22 \\
\hline Chung & $68.96 \pm 23.93$ & 34.71 & $52.00 \pm 8.35$ & 16.06 \\
\hline Jember & $57.83 \pm 18.87$ & 32.64 & $37.78 \pm 8.64$ & 22.88 \\
\hline Situbondo GL & $87.83 \pm 34.22$ & 38.96 & $59.78 \pm 8.60$ & 14.39 \\
\hline Makassar3 & $62.33 \pm 25.27$ & 40.54 & $50.67 \pm 7.60$ & 15.00 \\
\hline Situbondo BK & $47.06 \pm 13.40$ & 28.47 & $53.11 \pm 7.49$ & 14.10 \\
\hline Lombok 3 & $84.67 \pm 21.21$ & 25.05 & $42.50 \pm 10.31$ & 24.26 \\
\hline Lombok 4 & $42.95 \pm 9.62$ & 22.39 & $50.67 \pm 6.95$ & 13.71 \\
\hline CLN 4046 & $72.85 \pm 23.59$ & 32.37 & $39.67 \pm 6.46$ & 16.29 \\
\hline Kefaminano 4 & $40.93 \pm 19.63$ & 47.96 & $38.33 \pm 7.20$ & 18.79 \\
\hline Bogor Cibanteng & $48.57 \pm 12.42$ & 25.57 & $41.17 \pm 9.77$ & 23.72 \\
\hline Kudamati 2 & $77.81 \pm 26.97$ & 34.67 & $46.67 \pm 8.67$ & 18.59 \\
\hline Gondol 2 & $73.85 \pm 25.34$ & 34.31 & $49.33 \pm 6.36$ & 12.90 \\
\hline Berlian & $53.89 \pm 18.46$ & 34.26 & $40.89 \pm 6.13$ & 15.00 \\
\hline
\end{tabular}


Keterangan : M1= generasi ke-1 (M0 yang telah diberikan perlakuan irradiasi sinar gamma), M0= tanpa perlakuan irradiasi sinar gamma.

Padatan terlarut total. Padatan terlarut total dinyatakan dalam satuan ${ }^{\circ}$ Brix. Nilai padatan terlarut total pada tomat bukan hanya menyatakan kandungan gula, namun juga asam organik, senyawa nitrogen terlarut atau mineral (Suarez et al., 2008).

Genotipe Chung pada tanaman M1 memiliki nilai padatan terlarut total tertinggi dengan nilai $6.89^{\circ}$ Brix, sedangkan terendah Aceh 5 dan Kefaminano 4 memiliki nilai yang sama yaitu $4.76{ }^{\circ}$ Brix. Koefisien keragaman tertinggi terdapat pada Kudamati 1 (94.32\%), dan terendah Situbondo BK (1.61\%).

Karakter padatan terlarut total tertinggi pada tanaman kontrol terdapat pada genotipe Tanah Datar dengan nilai $6.75^{\circ}$ Brix, dan terendah Jember dengan nilai $4.67{ }^{\circ}$ Brix. Nilai koefisien keragaman tertinggi pada genotipe Bogor Cibanteng (10.83\%), sedangkan keragaman terendah Situbondo GL, dan Gondol $2(0.00 \%)$.

Tabel 15. Nilai tengah, simpangan baku, dan koefisien keragaman padatan terlarut total genotipe tomat M1 dan M0

\begin{tabular}{lcccc}
\hline \multirow{2}{*}{ Genotipe } & \multicolumn{2}{c}{ M1 } & \multicolumn{2}{c}{ M0 } \\
\cline { 2 - 5 } \multicolumn{1}{c}{$\bar{x} \pm \alpha\left({ }^{\circ}\right.$ Brix $)$} & KK $(\%)$ & $\bar{x} \pm \alpha\left({ }^{\circ}\right.$ Brix $)$ & KK $(\%)$ \\
\hline Kudamati 1 & $5.99 \pm 5.65$ & 94.32 & $5.40 \pm 0.17$ & 3.21 \\
Kefaminano 6 & $5.30 \pm 1.08$ & 20.32 & $5.27 \pm 0.12$ & 2.19 \\
Aceh 1 & $5.03 \pm 0.88$ & 17.43 & $5.40 \pm 0.26$ & 4.90 \\
Lombok1 & $5.05 \pm 1.37$ & 27.05 & $4.80 \pm 0.17$ & 3.61 \\
Aceh 5 & $4.76 \pm 0.92$ & 19.24 & $5.20 \pm 0.26$ & 5.09 \\
Kemir & $5.06 \pm 0.65$ & 12.87 & $5.23 \pm 0.15$ & 2.92 \\
Chung & $6.89 \pm 1.20$ & 17.43 & $5.27 \pm 0.23$ & 4.38 \\
Jember & $6.17 \pm 1.33$ & 21.55 & $4.67 \pm 0.29$ & 6.19 \\
Situbondo GL & $5.33 \pm 0.54$ & 10.16 & $6.20 \pm 0.00$ & 0.00 \\
Makassar3 & $5.75 \pm 1.60$ & 27.91 & $5.33 \pm 0.15$ & 2.86 \\
Situbondo BK & $5.07 \pm 0.08$ & 1.61 & $5.05 \pm 0.07$ & 1.40 \\
Lombok 3 & $5.93 \pm 0.52$ & 8.70 & $5.13 \pm 0.23$ & 4.50 \\
Lombok 4 & $5.16 \pm 0.79$ & 15.32 & $5.17 \pm 0.31$ & 5.91 \\
CLN 4046 & $6.06 \pm 1.40$ & 23.20 & $5.10 \pm 0.20$ & 3.92 \\
Kefaminano 4 & $4.76 \pm 0.55$ & 11.50 & $5.00 \pm 0.14$ & 2.83 \\
Bogor Cibanteng & $5.93 \pm 1.62$ & 27.37 & $5.33 \pm 0.58$ & 10.83 \\
Kudamati 2 & $5.64 \pm 1.49$ & 26.40 & $5.90 \pm 0.20$ & 3.39 \\
Gondol 2 & $5.09 \pm 0.11$ & 2.13 & $5.60 \pm 0.29$ & 0.00 \\
Berlian & $7.03 \pm 1.04$ & 14.72 & $4.83 \pm 0.29$ & 5.97 \\
Tanah Datar & $4.97 \pm 0.50$ & 10.17 & $6.75 \pm 0.07$ & 1.05 \\
\hline Keterangan : & M1= generasi ke-1 (M0 yang telah diberikan perlakuan irradiasi sinar gamma), M0= tanpa perlakuan irradiasi sinar \\
& & & &
\end{tabular}

Bobot panen. Karakter bobot panen merupakan komponen produksi yang dapat digunakan untuk mengukur kualitas dari buah tomat. Tanaman tomat dengan perlakuan iradiasi sinar gamma 495, bobot panen tertinggi pada genotipe Aceh 5 dengan nilai tengah $133.00 \mathrm{~g}$, dan terendah Situbondo BK 13.42 g. Koefisien keragaman tertinggi terdapat pada Situbondo BK (134.27\%), sedangkan keragaman terendah CLN $4046(48.17 \%)$.

Berdasarkan pengamatan pada bobot panen, tanaman kontrol dengan bobot tertinggi yaitu Kudamati 1 dengan nilai tengah $185.83 \mathrm{~g}$, dan terendah Berlian dengan nilai tengah $20.49 \mathrm{~g}$. Keragaman tertinggi terdapat pada Kefaminano 4 (102.03\%), sedangkan keragaman terendah Aceh $5(18.50 \%)$. Terdapat beberapa genotipe pada tanaman tomat 495 Gy yang memiliki bobot panen lebih tinggi daripada tanaman kontrol antara lain Aceh 5 (133.00 g), Lombok 4 (54.27 g), dan Kefaminano 4 (97.95 g). Hal ini menunjukkan bahwa pengaruh dari iradasi sinar gamma dapat meningkatkan bobot panen pada beberapa genotype (Tabel 16).

\section{KESIMPULAN}

Perlakuan iradiasi pada benih tomat dengan iradiasi sinar gamma 495 Gy menyebabkan adanya keragaman pada keragaan genotipe, baik pada karakter kualitatif maupun kuantitatif. Terdapat beberapa genotipe M1 yang memiliki keragaan kualitatif tipe helai daun, letak petiole, susunan bunga, tangkai bunga, dan karakter hasil yang berbeda dibandingkan M0 yaitu Kefaminano 6, Kefaminano 4, Situbondo GL, Lombok 4, Lombok 1, Gondol 2, Kudamati 1, Aceh 1, Makassar 3, Bogor Cibanteng, Berlian, 
CLN 4046, dan Kemir. Berdasarkan bobot panen diperoleh tiga genotipe dengan produksi lebih

Tabel 16. Nilai tengah, simpangan baku, dan koefisien

\begin{tabular}{lrrrr}
\multicolumn{2}{c}{ Tabel 16. Nilai tengah, simpangan baku, dan koefisien keragaman bobot panen genotipe tomat M1 dan M0 } \\
\cline { 2 - 5 } \multicolumn{2}{c}{ Genotipe } & \multicolumn{2}{c}{ M1 } & \multicolumn{2}{c}{ M0 } \\
\cline { 2 - 5 } & \multicolumn{1}{c}{$\pm \alpha(\mathrm{g})$} & 65.48 & $185.83 \pm 86.67$ & KK $(\%)$ \\
\hline Kudamati 1 & $114.45 \pm 74.94$ & 85.78 & $161.41 \pm 116.30$ & 72.64 \\
Kefaminano 6 & $118.25 \pm 101.43$ & $68.67 \pm 46.77$ & 68.10 \\
Aceh 1 & $55.83 \pm 33.26$ & 59.57 & $183.68 \pm 65.64$ & 35.74 \\
Lombok1 & $115.65 \pm 57.59$ & 49.80 & $27.15 \pm 5.02$ & 18.50 \\
Aceh 5 & $133.00 \pm 114.04$ & 85.75 & $151.60 \pm 138.63$ & 91.45 \\
Kemir & $76.18 \pm 61.14$ & 80.26 & $44.42 \pm 28.07$ & 63.19 \\
Chung & $24.15 \pm 28.05$ & 116.14 & $85.74 \pm 70.79$ & 82.56 \\
Jember & $81.20 \pm 44.00$ & 54.19 & $160.43 \pm 157.75$ & 98.33 \\
Situbondo GL & $79.12 \pm 46.54$ & 58.83 & $129.23 \pm 73.32$ & 56.74 \\
Makassar3 & $102.97 \pm 76.70$ & 74.48 & $68.17 \pm 17.42$ & 25.56 \\
Situbondo BK & $13.42 \pm 18.02$ & 134.27 & $138.72 \pm 65.88$ & 47.49 \\
Lombok 3 & $95.47 \pm 89.19$ & 93.42 & $47.59 \pm 28.33$ & 59.52 \\
Lombok 4 & $54.27 \pm 31.60$ & 58.22 & $38.31 \pm 24.41$ & 63.73 \\
CLN 4046 & $30.65 \pm 14.77$ & 48.17 & $63.26 \pm 64.55$ & 102.03 \\
Kefaminano 4 & $97.95 \pm 57.42$ & 58.62 & $85.48 \pm 81.17$ & 94.96 \\
Bogor Cibanteng & $76.31 \pm 79.85$ & 104.65 & $128.36 \pm 78.25$ & 60.96 \\
Kudamati 2 & $126.58 \pm 90.09$ & 71.17 & $126.40 \pm 97.55$ & 77.18 \\
Gondol 2 & $97.97 \pm 63.18$ & 64.49 & $20.49 \pm 13.69$ & 66.81 \\
Berlian & $18.02 \pm 10.44$ & 57.92 & $43.83 \pm 32.03$ & 73.08 \\
Tanah Datar & $31.77 \pm 16.27$ & 51.22 & & \\
\hline Keterangan : & M1= generasi ke-1 (M0 yang telah diberikan perlakuan irradiasi sinar gamma), M0= tanpa perlakuan irradiasi sinar \\
& & & &
\end{tabular}

Keterangan : $\quad$ M1 = generasi ke-1 (M0 yang telah diberikan perlakuan irradiasi sinar gamma), M0= tanpa perlakuan irradiasi sinar gamma.

\section{DAFTAR PUSTAKA}

Aisyah, S.I. 2006. Sitogenetika Tanaman. Sarsidi S, editor. Fakultas Pertanian (ID): Institut Pertanian Bogor.

Allard, R.W. 1995. Pemulian Tanaman. Manna, penerjemah; Mulyani M, editor. Jakarta (ID): PT Rineka Cipta. Terjemahan dari: Principle of Plant Breeding. Ed ke-2.

[BPSRI] Badan Pusat Statistik Republik Indonesia. 2013a. Produksi sayuran dan buah-buahan semusim di Indonesia, 19972013. Jakarta (ID): BPSRI.

[BPSRI] Badan Pusat Statistik Republik Indonesia. 2013b. Luas panen dan produktivitas hortikultura di Indonesia, 2012-2013. Jakarta (ID): BPSRI.

Cahyono, B. 2008. Usaha Tani dan Penanganan Pasca Panen. Yogyakarta (ID): Kanisius.

Florida Tomato Committee. 2015. Maturity and ripening stages for tomato. [Internet]. [diunduh 2015 Jan 12]. Tersedia pada: http//www.Floridatomato committe.org. unggul dibandingkan dengan tanaman kontrol yaitu Aceh 5, Lombok 4, dan Kefaminano 4.

Gumelar, R. M. 2014. Karakterisasi dan respon pemangkasan air terhadap produksi serta kualitas buah lima genotipe tomat lokal [skripsi]. Bogor (ID): Institut Pertanian Bogor.

Hidayat, A. 1997. Ekologi tanaman tomat. Teknologi Produksi Tomat. Lembang (ID): Balai Penelitian Tanaman Sayuran.

Ikeda, H. Hiraga, M. Shirasawa, K., Nishiyama, M. Kanahama, K. dan Kanayama, Y.2013.

Analysis of a tomato introgression line IL83 with increased brix content. Scientia Horticulture. 153(2013):103-108.

Jones JB. 2008. Tomato Plant Culture in the Field, Greenhouse, and Home Garden. Second edition. New York (US): CRC Press Taylor and Francis Group

Lingga, L. 2010. Cerdas Memilih Sayuran. Nixon MT, editor. Jakarta (ID): Agro Media Pustaka.

Ratnasari. 2007. Evaluasi keragaman fenotipe melati (Jasmimum spp.) hasil iradiasi berulang sinar gamma [skripsi]. Bogor (ID): Institut Pertanian Bogor. 
[PUSDATIN] Pusat Data dan Sistem Informasi Pertanian. 2008. Konsumsi sayuran per kapita, 2006-2008. Jakarta (ID): Sekretariat Jenderal Kementerian Pertanian.

[PUSDATIN] Pusat Data dan Sistem Informasi Pertanian. 2014. Ekspor dan impor komoditi pertanian subsektor hortikultura 2014. Jakarta (ID): Sekretariat Jenderal Kementerian Pertanian.

Purwati. 2007. Evaluasi lapangan keragaman genotipe-genotipe somaklonal Artemisia (Artemisia annua L.) hasil induksi mutan iradiasi sinar gamma [skripsi]. Bogor (ID): Institut Pertanian Bogor.

Rubatzky. E. dan Yamaguchi, M. 1999. Sayuran Dunia; Prinsip,Produksi, dan Gizi. Herison C, penerjemah; Niksolihin S, editor. Bandung (ID): ITB. Terjemahan dari: World Vegetables: Principles, Production, and Nutritive Value. Ed ke-3.
Suarez, M. H, Rodriguez EM, Romero CD. 2008. The chemical composition and nutritional value of tomato. Food Chemistry. 106(2008): 1046-1056.

Susila, A. D. 1995. Studi pecah buah (fruit cracking) dalam rangka peningkatan kualitas buah tomat (Lycopersicon esculentum Mill. L). [tesis] Bogor (ID): Institut Pertanian Bogor.

Syukur, M., Sujiprihati, S., dan Yunianti, R. 2012. Teknik Pemuliaan Tanaman. Jakarta (ID): Penebar Swadaya

[UPOV] International Union For The Protection Of New Varieties Of Plants. Description for Tomato (Solanum lycopersicum L). Geneva (UE): UPOV.

Wahyudi. 2012. Bertanam Tomat. Jakarta (ID): Agromedia.

Yudiwanti. 2006. Sitogenetika Tanaman. Sarsidi S, editor. Fakultas Pertanian (ID): Institut Pertanian Bogor. 